\title{
Ontogeny of Estrogen Receptor (ER) $\alpha$ and $\beta$ in the Female Reproductive Tissues of Mice Neonatally Exposed to Diethylstilbestrol
}

\author{
Shuji Yamashita ${ }^{1}$ \\ ${ }^{1}$ Keio Junior College of Nursing, 35 Shinanomachi, Shinjuku-ku, Tokyo 160-8582
}

Received June 5, 2002; accepted September 2, 2002

Ontogenical expression of estrogen receptor (ER) isoforms, ER $\alpha$ and $E R \beta$, was examined in order to study the roles of the isoforms in the morphogenesis of neonatal diethylstilbestrol (DES) treatment in the female reproductive tissues using an immunohistochemical method. The intensity of ER $\alpha$ immunostaining gradually increased with aging in the epithelial cells of oviducts, uteri, cervices and vaginae in the vehicle-treated control animals. Neonatal DES-treatment up-regulated the expression of ER $\alpha$ in the epithelial cells in these tissues and down-regulated it in the stromal cells at least until 10 days of age including the period of DES-treatment. On day 21, both control and DES-mice showed almost similar ER $\alpha$ distribution in these tissues. There were no differences in the ER $\alpha$ distribution in the ovaries of two experimental groups. ER $\alpha$ was localized in the theca cells and some stromal cells located interfollicularly. Neonatal DES exposure did not influence the distribution pattern of ER $\beta$ protein during the period of treatment and postnatal development. The nuclear ER $\beta$-immunoreaction was seen in the granulosa cells of ovaries but not in the cells of reproductive tracts. These results demonstrated that $E R \alpha$ is the critical ER isoform for the estrogen-dependent responses in the normal female genital tract, and that the presence of ER $\alpha$ in the epithelial cells during the period of DES exposure should play important roles in the the induction of abnormal characteristics in the genital tract of DES-mice.

Key words: Estrogen receptor $\alpha$, Estrogen receptor $\beta$, Diethylstilbestrol, Mouse

\section{Introduction}

Estrogen administration to prenatal or neonatal rodents induces a wide range of abnormalities including carcinogenesis in both the female and male reproductive organs [1, $8,20,32]$. These effects are mediated by hormone-occupied estrogen receptors (ERs) which regulate the transcription of target genes by binding to their estrogen responsive elements (EREs). Recent studies have demonstrated that there are two types of ERs, ER $\alpha$ (the classical type) and ER $\beta$ (the newly discovered type), and that $\mathrm{ER} \alpha$ is the major isoform in the female genital tract and ER $\beta$ is the prominent isoform in the ovary in normal rodents [6, 17]. Although both ER isoforms show a high affinity to estrogens including diethylstilbestrol (DES), a synthetic estrogen, and modulate target genes, both ERs appear to have unique and sometimes opposite roles [27]; ER $\beta$ acts to restrain the stimulative roles of

Correspondence to: Shuji Yamashita, Keio Junior College of Nursing, 35 Shinanomachi, Shinjuku-ku, Tokyo 160-8582, Japan.
$\mathrm{ER} \alpha$ in the rodent uterus [36].

Liganded ERs have been reported to crosstalk with other signaling pathways. ERs interact with the activator protein-1 (AP-1), complexes of c-fos and c-jun family proteins and to modulate the (AP-1) regulating gene transcription without direct binding to DNA [9, 27, 28]. Furthermore, membrane-mediated transducing pathways which are modulated by dopamine and polypeptide growth factors such as epidermal growth factor (EGF) and transforming growth factor $\alpha(\mathrm{TGF} \alpha)$ are thought to regulate the activities of ERs through phosphorylation [7, 22, 26]. Recently, neonatal DES exposure has shown to induce a persistent activation of c-fos and EGF gene expression in a hormone-independent manner in the uteri of mature and immature mice $[23,40]$. Constitutive and interactive activation of these ER-regulating pathways should be responsible for the induction of abnormalities in the genital tract perinatally exposed to DES.

Ontogeny of ER expression in the reproductive tract of neonatal rodents has been of interest in connection with the molecular basis of hormonal regulation of morphogenesis, 
and estrogenic responses such as proliferation and differentiation elicited by exogenous estrogen administration in the neonatal reproductive tract. The responses to exogenous estrogens were thought to be mediated through the ER system in the stroma, since earlier studies using steroid autoradiograph localized ERs only in the stromal cells but not in the epithelium in the female reproductive tract of neonatal mice [2]. However, immunohistochemical studies have demonstrated that ER $\alpha$ is present in the epithelium of the oviduct, cervix and vagina even in newborn mice and in the uterine epithelium on day 4 after birth [16,37].

Neonatal DES treatment should influence the ER system of both stromal and epithelial cells during the period of neonatal DES exposure even in the uterus, because a single DES injection increased ER $\alpha$ protein and mRNA levels within several hours in the uterine epithelial cells of newborn and 4-day-old mice [30, 37]. In addition, perinatal DES treatment was reported to accelerate the onset of ER $\alpha$ synthesis in the uterine, cervical and vaginal epithelium of neonatal mice $[11,31]$. However, the distribution of ER isoforms has not been examined during the period of DES exposure and during maturation of female reproductive tissues. In this study, in order to elucidate the roles of each ER isoform in the morphogenesis of neonatal DES treatment, ontogenical expression of ER $\alpha$ and $E R \beta$ isoforms was examined in the female reproductive tissues of neonatally DES exposed mice (DES-mice) using an immunohistochemical method.

\section{Materials and Methods}

\section{Animals and tissue preparation}

Pregnant CD-1 mice were obtained from Clea Japan Inc. (Tokyo). Mice were housed at 21 to $22^{\circ} \mathrm{C}$ with a $12 \mathrm{hr}$ alternating light-dark cycle at Keio University Animal Facility, Tokyo, Japan. All animals were maintained and treated with the protocols which were approved by the Keio University Animal Care Committee. Mice were subcutaneously injected with $4 \mu \mathrm{g}$ of DES (Sigma Chem., St. Louis, MO) dissolved in $0.02 \mathrm{ml}$ sesame oil or the vehicle alone for 5 days, starting within $24 \mathrm{hr}$ after birth: birth of day is day 1 . Neonatal injections of few $\mu \mathrm{g}$ of DES have been shown to induce uterine squamous metaplasia and tumor, heterotropic columnar epithelium in the cervix, and irreversible vaginal proliferation and cornification in mice [8, 13, 24]. Six or seven animals of each experimental group were killed on days 4 (after 3 injections), 10, 15 and 21. Tissues were collected, mounted in OCT compound and then frozen in dry ice-cooled acetone. Frozen sections $7 \mu \mathrm{m}$ thick were fixed with $4 \%$ paraformaldehyde dissolved in $0.15 \mathrm{M}$ phos-

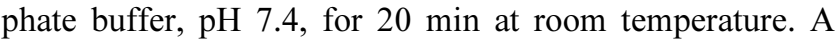
preliminary experiment showed that higher molarity of phosphate buffer could minimize the extraction of unliganded ER $\alpha$ during fixation, so a $0.15 \mathrm{M}$ phosphate buffer was employed to dissolve paraformaldehyde in this study.

\section{Immunohistochemistry}

Localization of ER $\alpha$

The fixed sections were washed with $10 \mathrm{mM}$ phosphate buffer, $\mathrm{pH} 7.4$ containing $0.85 \% \mathrm{NaCl}$ (PBS), treated with $0.2 \%$ glycine in PBS for $30 \mathrm{~min}$ and successively with the blocking solution, $1 \%$ bovine serum albumin and $1 \%$ blocking reagent (Boehringer Mannheim, Mannheim, Germany) dissolved in PBS, for $60 \mathrm{~min}$. The sections were incubated with anti-ER $\alpha$ rabbit polyclonal antibody (MC-20, lot, G260, Santa Cruz Biotech., Santa Cruz, CA) overnight at $4{ }^{\circ} \mathrm{C}$; the antibody was diluted 1000 -fold with the blocking solution. For the control immunostaining, antibody pre-absorbed with antigen peptide (sc-542P, Santa Cruz Biotech.) or normal rabbit IgG were used as the primary antibodies. Some sections were incubated with anti-ER rat monoclonal antibody (Abbott Laboratories, Abbot Park, IL) to compare with the previous our results concerning ontogenic ER $\alpha$ expression which were obtained from mice without any treatment [37]. After washing with PBS, they were then treated with anti-rabbit Ig, horseradish peroxidase (HRP) linked $\left.\mathrm{F}(\mathrm{ab})_{2}\right)_{2}$ fragments or rat Ig, HRP linked $\left.\mathrm{F}(\mathrm{ab})_{2}\right)_{2}$ fragments (Amersham Life Sci., UK), each 100-fold diluted with the blocking solution, for $90 \mathrm{~min}$ at room temperature. The peroxidase enzyme activity was detected with imidazole-3,3'diaminobenzidine (DAB) solution. Sections were examined without further counterstaining.

\section{Localization of ER $\beta$}

ER $\beta$ was localized using the ABC procedure. In order to block an endogenous avidin binding activity, fixed sections were treated with avidin, $0.2 \mathrm{mg} / \mathrm{ml}$, dissolved in 10 $\mathrm{mM}$ phosphate buffer, $\mathrm{pH} 7.4$ containing $0.4 \mathrm{M} \mathrm{NaCl}$, for $60 \mathrm{~min}$, washed with PBS, and then incubated with biotin, $2 \mathrm{mg} / \mathrm{ml}$, dissolved in $10 \mathrm{mM}$ phosphate buffer, $\mathrm{pH} 7.4$ containing $0.4 \mathrm{M} \mathrm{NaCl}$, for $30 \mathrm{~min}$. They were washed with PBS, treated with the blocking solution for $60 \mathrm{~min}$ and then incubated with anti-ER $\beta$ polyclonal goat antibody (Y19, lot, K309, Santa Cruz Biotech.), 150-fold dilution with the blocking solution, overnight at $4{ }^{\circ} \mathrm{C}$. Tyulmenkov and Klinge [34] showed that the antibody Y-19 was the most sensitive and selective ER $\beta$ antibody because it supershifted all of the ER $\beta$-ERE complex, but did not affect ER $\alpha$-ERE binding. The antibody was also shown to react with $\operatorname{ER} \beta$, giving a $54 \mathrm{kd}$ polypeptide in the Western blot analysis [33]. The antibody pre-incubated with antigen peptide (sc-6821P, Santa Cruz Biotech.) was used in place of the specific antibody as a control. The sections were then incubated with biotin-labeled anti-goat IgG (Vectorstain ABC kit; Vector Lab. Inc., Burlingame, CA) for $60 \mathrm{~min}$, successively with $\mathrm{ABC}$ complex for $30 \mathrm{~min}$. Both the biotinylated antibody and the $\mathrm{ABC}$ complex were dissolved in the blocking solution. After the sections were washed with PBS and successively with $10 \mathrm{mM}$ phosphate buffer, $\mathrm{pH} 7.4$ containing $0.4 \mathrm{M} \mathrm{NaCl}$, they were incubated with the imidazoleDAB solution. 


\section{Results}

Both polyclonal antibody and monoclonal antibodies exhibited similar ER $\alpha$ distribution patterns. Antigen retrieval or exposure procedures were examined for the immunohistochemistry of both ER isoforms [12, 41]. However, when the fixed frozen sections were autoclaved or microwaved in buffers, ER $\alpha$-immunostaining using MC-20 antibody was reduced and ER $\beta$-immunostaining with $\mathrm{Y}-19$ was abolished. Ontogenic expression of ER $\alpha$ and ER $\beta$ in the female reproductive tissues of vehicle-treated controls and DES-mice was summarized in Table 1.

\section{Localization of ER $\alpha$ \\ Ovary}

Neonatal DES treatment elicited no significant histo- logical changes in the ovaries. However, follicles containing two oocytes were sometimes recognized in the DES-mice on day 21 .

The intensity of immunostaining and distribution pattern of ER $\alpha$ was almost the same in both experimental groups during maturation. Theca cells and some stroma cells located interfollicularly exhibited positive ER $\alpha$-immunoreaction and the intensity of immunostaining gradually increased with aging (Fig. 1a-d). Some germinal epithelium displayed a weak staining.

\section{Oviduct}

On day 4, longitudinal folds were more developed in the DES-mice than in the controls (Fig. 2a, b). The epithelial cells were simple cuboidal or columnar cells in the controls and ranged from simple columnar to pseudostratified in

Table 1. Ontogeny of ER $\alpha$ and ER $\beta$ in the female reproductive tissues of neonatally DES-treated mice

\begin{tabular}{|c|c|c|c|c|c|c|c|c|c|}
\hline \multirow{3}{*}{ ERs } & \multirow{3}{*}{ Tissues and Cells } & \multicolumn{8}{|c|}{ Postnatal Days } \\
\hline & & \multicolumn{2}{|c|}{ Day 4} & \multicolumn{2}{|c|}{ Day 10} & \multicolumn{2}{|c|}{ Day 15} & \multicolumn{2}{|c|}{ Day 21} \\
\hline & & Control & DES & Control & DES & Control & DES & Control & DES \\
\hline \multirow[t]{22}{*}{$\mathrm{ER} \alpha$} & Ovary & & & & & & & & \\
\hline & Oocytes & 0 & 0 & 0 & 0 & 0 & 0 & 0 & 0 \\
\hline & Granulosa Cells & 0 & 0 & 0 & 0 & 0 & 0 & 0 & 0 \\
\hline & Theca/Stroma Cells & 1 & 1 & $1-2$ & $1-2$ & 2 & 2 & 3 & 3 \\
\hline & Oviduct & & & & & & & & \\
\hline & Epithelium & 1 & $2-3$ & $1-3^{a}$ & $1-4^{a}$ & $1-4^{a}$ & $1-4^{a}$ & $1-4^{\mathrm{a}}$ & $1-4^{a}$ \\
\hline & Stroma & $2-3$ & 2 & $2-3$ & 2 & $2-3$ & $2-3$ & $2-3$ & $2-3$ \\
\hline & Uterus & & & & & & & & \\
\hline & Epithelium & 0 & $2-3$ & $1-2^{\mathrm{b}}$ & $2-3$ & $2-3^{b}$ & $3-4$ & $3-4^{b}$ & $3-4^{b}$ \\
\hline & Stroma & 2 & $2-3$ & 3 & 2 & 3 & 2 & 3 & 3 \\
\hline & Cervix & & & & & & & & \\
\hline & Epithelium & & & & & & & & \\
\hline & Columnar Cells & $0-1$ & 2 & & 2 & & & & \\
\hline & St. Cuboidal Cells & & & $1-2$ & $1-2$ & $1-3^{\mathrm{c}}$ & $1-3^{c}$ & $1-3^{\mathrm{c}}$ & $1-3^{\mathrm{c}}$ \\
\hline & Stroma & 2 & $1-2$ & 2 & 1 & 2 & 1 & 2 & 2 \\
\hline & Vagina & & & & & & & & \\
\hline & Epithelium & & & & & & & & \\
\hline & Columnar Cells & & 2 & & & & & & \\
\hline & St. Cuboidal Cells & $0-1$ & & $1-2$ & & $1-3^{\mathrm{c}}$ & & & \\
\hline & St. Squamous Cells & & 1 & & $0-2^{\mathrm{d}}$ & & $0-2^{\mathrm{d}}$ & $0-2^{\mathrm{d}}$ & $0-2^{\mathrm{d}}$ \\
\hline & Mucified cells & & & & & & & 2 & 2 \\
\hline & Stroma & 2 & $1-2$ & 2 & $1-2$ & 2 & $1-2$ & 2 & $2-3$ \\
\hline \multirow[t]{4}{*}{ ER $\beta$} & Ovary & & & & & & & & \\
\hline & Oocytes & 0 & 0 & 0 & 0 & 0 & 0 & 0 & 0 \\
\hline & Granulosa Cells & 1 & 1 & 2 & 2 & $2-3$ & $2-3$ & 3 & 3 \\
\hline & Theca/Stroma Cells & 0 & 0 & 1 & 1 & $2^{\mathrm{e}}$ & $2^{\mathrm{e}}$ & $2^{\mathrm{e}}$ & $2^{\mathrm{e}}$ \\
\hline
\end{tabular}

Intensity of ER $\alpha$-immunoreaction using antibody MC-20 was graded: 4, intense (reaction in the uterine galndular epithelium of control mice on day 21); 3, strong; 2, moderate; 1, weak; 0, none. ER $\beta$-immunostaining with antibody Y-19: 3, strong (reaction in the granulosa cells of maturationg follicles on days 15 and 21); 2, moderate; 1, weak; 0, none. ${ }^{a}$ Immunoreaction was heterogeneous, particullary in the infundibulum and ampulla. ${ }^{\mathrm{b}}$ The grandular epithelium exhibited stronger reaction than luminal epithelium. ${ }^{\mathrm{c}}$ ER $\alpha$-immunostaining was heterogeneous in the stratified cuboidal cells; cells of the basal layer and some cells of the upper layers showed a strong reaction. ${ }^{\mathrm{d}}$ Only cells of basal layer were positive. ${ }^{\mathrm{e}} \mathrm{A}$ small number of stromal and theca cells exhibited a moderate reaction. 

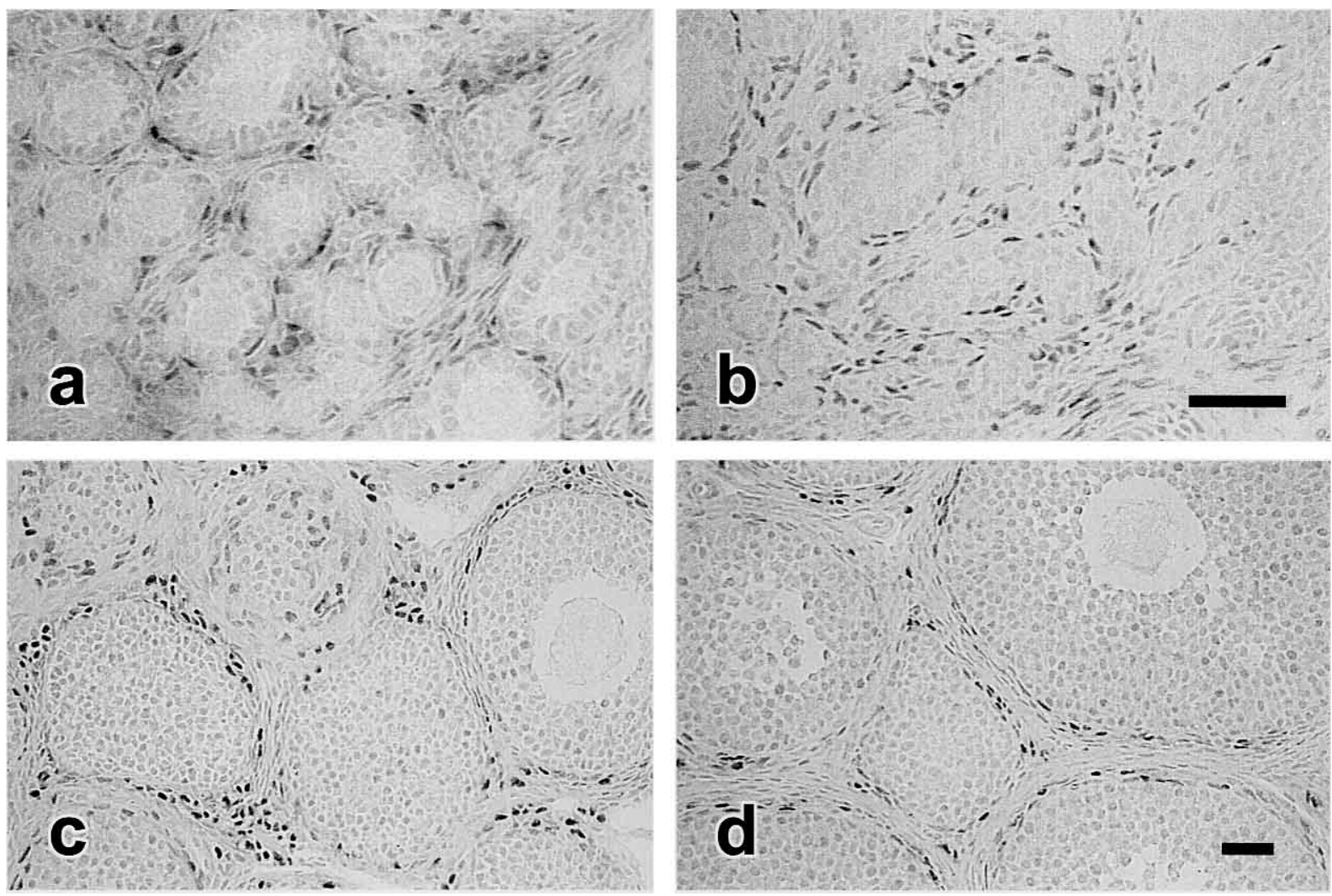

Fig. 1. Immunohistochemistry of of estrogen receptor $\alpha(E R \alpha)$ in the ovaries. ER $\alpha$ is localized in the ovaries of neonatally vehicle-treated controls (a and c) and of diethylstilbestrol (DES) exposed mice, DES-mice, (b and d), on postnatal day 4 (a and b) and day 21 (c and d). All figures shown in this paper represent the ER $\alpha$ distribution in frozen sections fixed with 4\% paraformaldehyde, using polyclonal antibody (MC-20). The intensity of immunostaining and distribution pattern of ER $\alpha$ are almost the same in both experimental groups on days 4 and 21 , respectively. ER $\alpha$-immunostaining is present in the stromal cells surrounding follicles on day 4 (a and $\mathbf{b})$ and in the theca cells and some stromal cells located interfollicularly on day 21 (c and d). Bars $=50 \mu \mathrm{m}(\mathbf{a}, \mathbf{b}), 50 \mu \mathrm{m}(\mathbf{c}, \mathbf{d})$.

DES-mice. No clear histological differences were recognized on days 10,15 and 21 .

In vehicle-treated control animals, the epithelial cells showed a weak ER $\alpha$-immunostaining on day 4 (Fig. 2a). Expression of $E R \alpha$ was heterogeneous in the epithelial cells of the infundibulum and ampulla on days 10, 15 and 21 (Fig. $2 \mathrm{c}, \mathrm{e})$, although the eithelial cells in the isthmus showed almost homogeneous and strong to intense ER $\alpha$-immunoreaction. Neonatal DES treatment activated ER $\alpha$ expression in the epithelium on days 4 and 10 (Fig. 2b, d). Stromal and muscle cells of DES-mice revealed weaker reaction than those of the controls on days 4 and 10 .

\section{Uterus}

In the oil-treated controls, the luminal epithelium was lined with simple columnar cells during maturation and the uterine glands were seen on day 10. In the DES-mice, the epithelium was hyperplastic and composed of pseudostratified columnar or simple high columnar cells on days 4, 10 and 15. The uteri demonstrated a smaller diameter and uterine glands were poorly developed compared with control mice on days 15 and 21 .

In the control animals, very faint ER $\alpha$-immunostaining was detectable in few epithelial cells on day 4 (Fig. 3a) and the staining gradually increased with maturation (Fig. $3 \mathrm{c}, \mathrm{e}$, $\mathrm{g})$. In the DES-mice, expression of ER $\alpha$ protein in the epithelium was highly up-regulated on days 4 and 10 (Fig. 3b, d) and it was almost the same as control animals on day 21 (Fig. 3i). The glandular epithelium showed stronger ER $\alpha$ immunostaining than the luminal epithelium in the controls (Fig. 3c, e, g), whereas luminal and glandular epithelium showed almost the same ER $\alpha$-immunostaining in the DESmice, particularly on days 10 and 15 (Fig. 3d, f). Immunoreaction in the stroma and muscle cells was weaker than that in the controls on days 10 and 15 and almost the same on day 21 .

In the control immunostaining, ER $\alpha$ antibody preabsorbed with immunizing peptide displayed very faint reaction (Fig. 3h) and normal rabbit IgG provided no specific immunostaining.

Cervix

In the control animals, the common cervical canal (CCC) was lined with simple columnar or pseudostratified columnar epithelium on day 4 , and with stratified cuboidal epithelium from day 10 to day 21 . In the DES-mice, the 

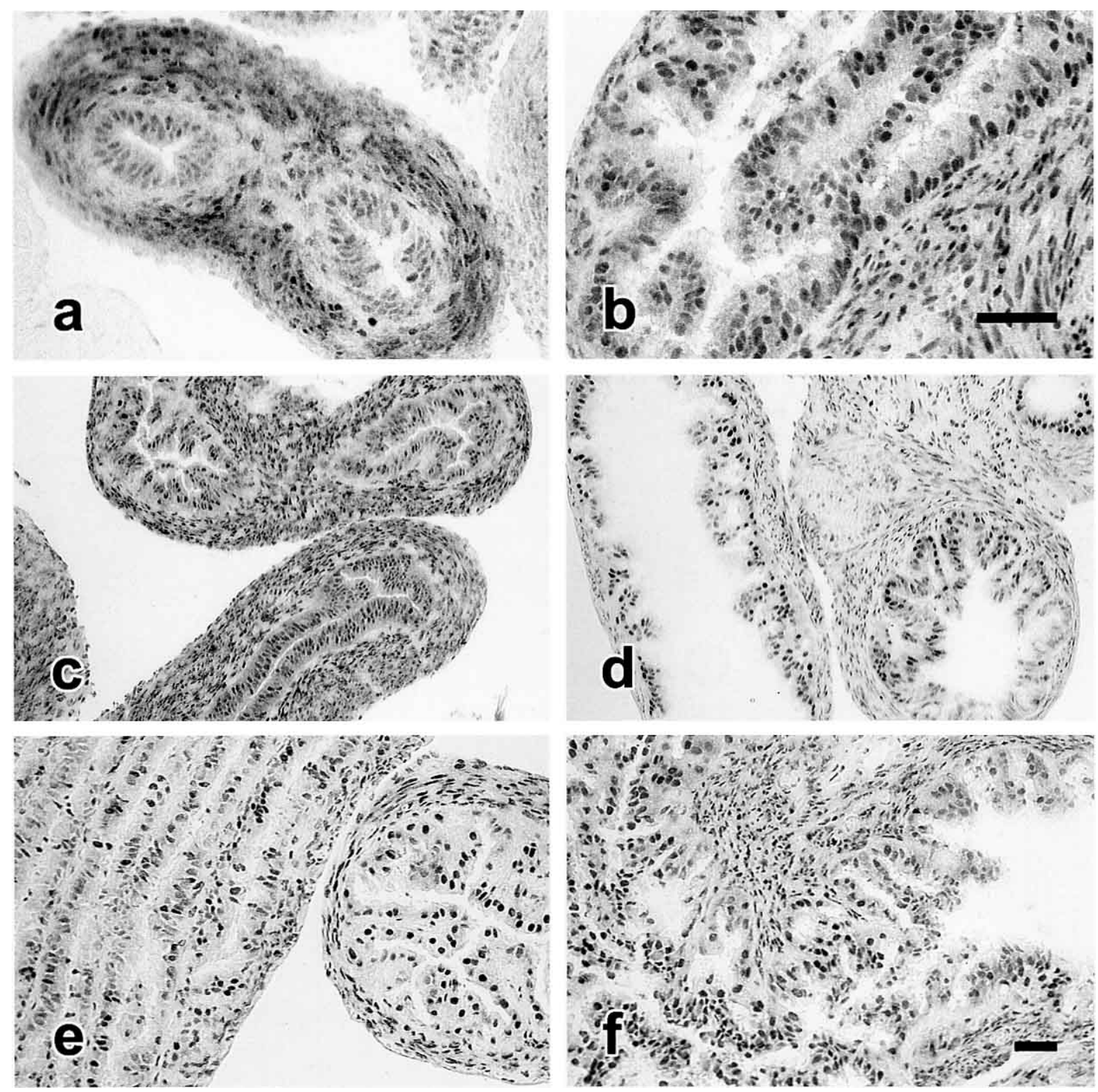

Fig. 2. Immunohistochemistry of ER $\alpha$ in the oviducts. ER $\alpha$ is shown in the oviducts of controls (a, $\mathbf{c}$ and e) and of DES-mice (b, $\mathbf{d}$ and $\mathbf{f})$, on day 4 (a and b), day 10 (c and d) and day 15 (e and f). Neonatal DES treatment up-regulates ER $\alpha$ expression in the epithelium on days 4 and 10 (b and d). Bars $=50 \mu \mathrm{m}(\mathbf{a}, \mathbf{b}), 50 \mu \mathrm{m}(\mathbf{c}-\mathbf{f})$.

CCC epithelium was pseudostratified columnar cells on day 4 ; in some regions, stratified squamous cells invaded under the columnar epithelium. Nodules of stratified cuboidal epithelium were present beneath the pseudostratified cells on day 10 (Fig. 4d). The CCC was lined principally with stratified cuboidal epithelium on days 15 and 21; in some regions, stratified squamous epithelium, the mucified cells and pseudostratified columnar epithelium were observed.

In the control animals, the intensity of ER $\alpha$-immunoreaction in the CCC epithelium gradually increased with maturation (Fig. 4a, c, e). The basal layer cells of stratified cuboidal epithelium showed a strong immunoreaction on days 15 and 21 (Fig. 4e). Neonatal DES treatment activated
ER $\alpha$ expression, particularly, on days 4 and 10. The CCC columnar epithelium showed a moderate reaction, and the basal layer cells of stratified epithelium exhibited weak to moderate reaction on days 4 and 10 (Fig. $4 \mathrm{~b}, \mathrm{~d}$ ) and a strong ER $\alpha$-immunoreaction on days 15 and 21 (Fig. 4f). Compressed nuclei of mucified cells exhibited positive immunostaining. Stromal cells showed weaker reaction in the DESmice than in the controls, in particular on days 10 and 15 . Infiltration of leucocytes showing endogenous peroxidase activity was also evident on days 10 and 15 (Fig. 4d).

\section{Vagina}

In the control mice, the vagina was lined with few 

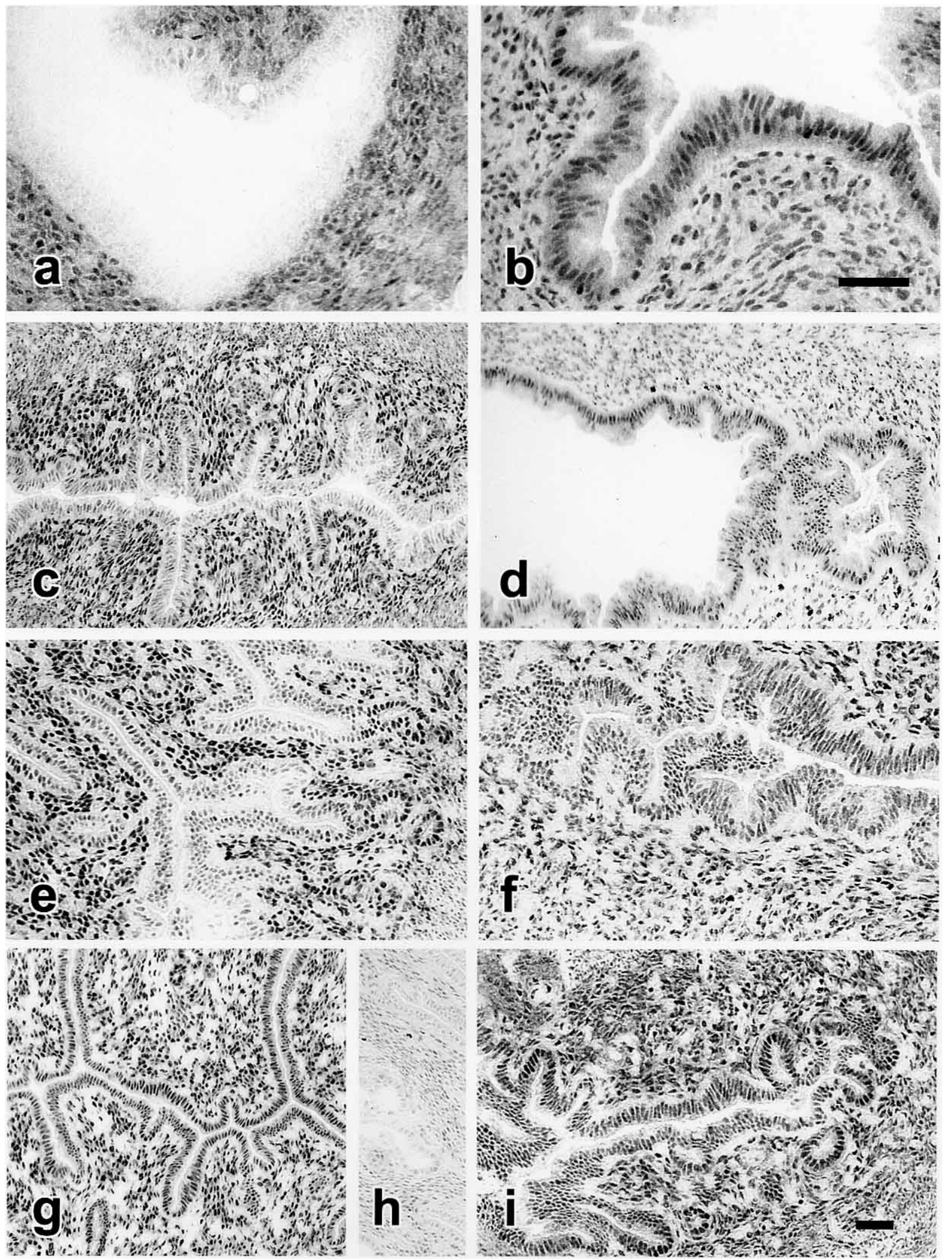

Fig. 3. Immunohistochemical staining of $E R \alpha$ protein in the uteri. ER $\alpha$ is localization in the uteri of oil-treated control animals (a, $, \mathbf{c}, \mathbf{e}, \mathbf{g}$ and $\mathbf{h})$ and of DES-mice ( $\mathbf{b}, \mathbf{d}, \mathbf{f}$ and $\mathbf{i}$ ), on day 4 (a and $\mathbf{b}$ ), day 10 ( $\mathbf{c}$ and $\mathbf{d})$, day 15 (e and $\mathbf{f}$ ) and day 21 (g, $\mathbf{h}$ and $\mathbf{i}$ ). ER $\alpha$-immunoreaction is hardly detectable in the epithelium in the control animal (a) but is strong in the DES-mouse (b) on day 4. Stronger ER $\alpha$-immunoreaction is also seen in the epithelium in the DES-mice than in controls on days 10 and 15 (c, d, e and f). For the control immunostaining, ER $\alpha$ antibody pre-absorbed antibody was used (h). Bars $=50 \mu \mathrm{m}(\mathbf{a}, \mathbf{b}), 50 \mu \mathrm{m}(\mathbf{c}-\mathbf{i})$. 

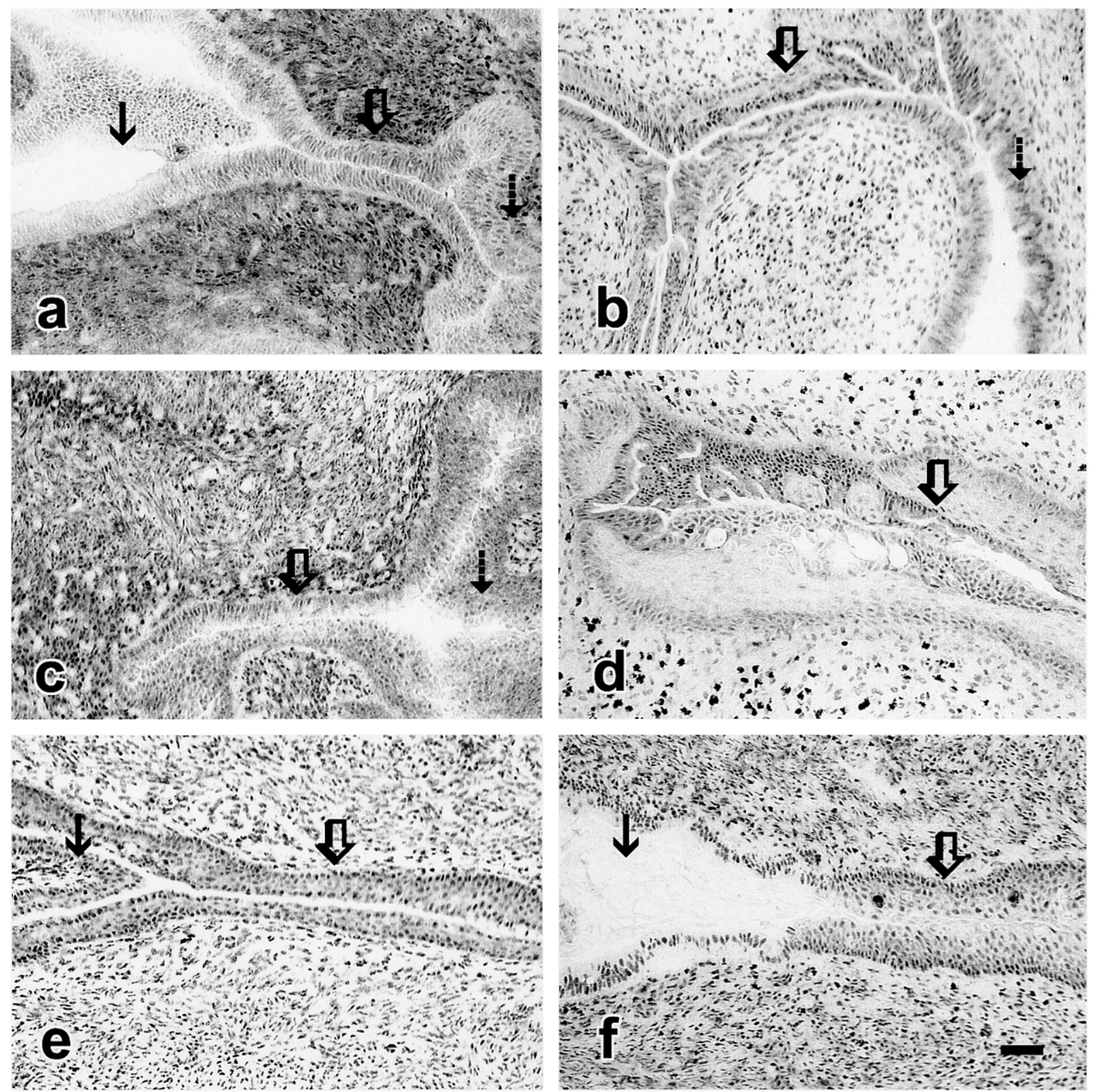

Fig. 4. Localization of ER $\alpha$ protein in the cervices. Figures show the cervices of control animals $(\mathbf{a}, \mathbf{c}$ and $\mathbf{e})$ and of DES-mice $(\mathbf{b}, \mathbf{d}$ and $\mathbf{f})$ on day 4 (a and b), day 10 (c and d) and day 21 (e and $\mathbf{f}$ ). In the controls, the epithelia of common cervical canal (CCC) are composed of pseudostratified columnar cells on day 4 (a) and stratified cuboidal epithelium on days 10 and 21 (c and e), respectively. These epithelial cells exhibit positive ER $\alpha$ immunoreaction. Neonatal DES treatment activates ER $\alpha$ expression on days 4 and 10 (b and $\mathbf{d})$. The pseudostratified columnar epithelium and the basal cells of stratified cuboidal epithelium represent ER $\alpha$ immunostaining on day 10 (d). Desquamation of keratinized squamous epithelium is seen in the lumen of uterus (f). Uterus $(\downarrow)$; CCC $(\mathbb{\downarrow})$; vagina $(\downarrow)$. Bar=50 $\mu \mathrm{m}$.

layers of stratified cuboidal epithelium on day 4 (Fig. 4a), with several layers of stratified cuboidal epithelium on days 10 and 15 (Fig. 5a, c), and with stratified squamous cells beneath the mucified cells on day 21 (Fig. 5e). In the DESmice, the epithelium consisted of stratified squamous epithelium covered with simple or pseudostratified columnar epithelium on day 4 (Fig. 4b). On day 10, a thick stratified squamous epithelium was seen with keratinization of the superficial cells in some parts; many leucocytes infiltrated into the stroma and the vaginal lumen. The epithelium con- sisted of stratified squamous cells with or without mucified cells on the surface on day 15 . On day 21 , the vaginal epithelium and luminal contents in the DES-mice were heterogeneous among animals. The sexual cycle may start: stratified squamous epithelium with mucified cells (cranial portion) and leucocytes in the lumen (1/6); keratinized squamous epithelium without any cell-types in the lumen (1/6); highly keratinized stratified squamous epithelium and many keratinized cells in the lumen (2/6); and stratified squamous epithelium and both keratinized cells and leucocytes in 

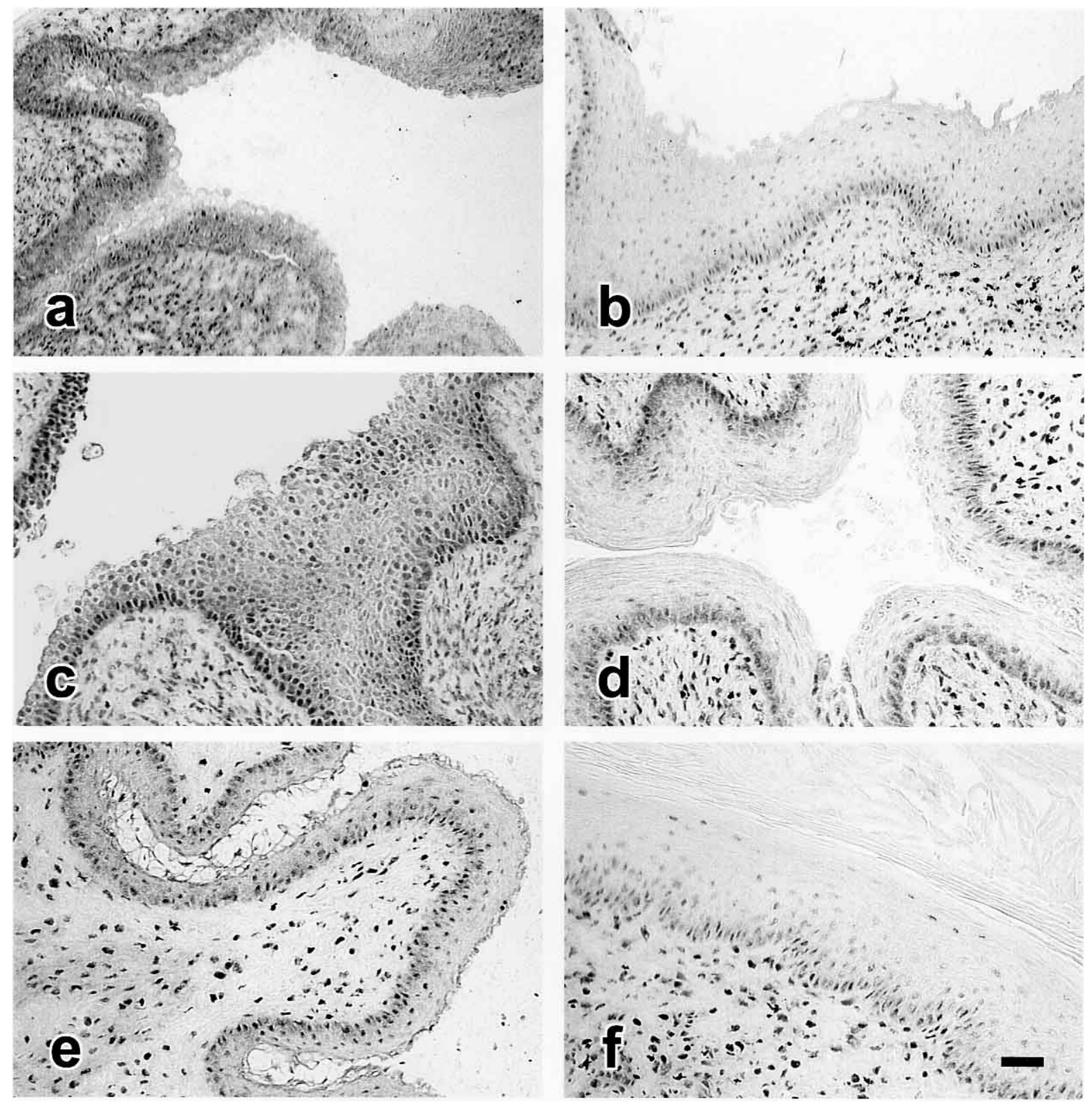

Fig. 5. Immunohistochemistry of $E R \alpha$ in the vaginae. ER $\alpha$ protein is localized in the vaginae of controls (a, $\mathbf{c}$ and $\mathbf{e})$ and of DES-mice (b, $\mathbf{d}$ and f) on day 10 (a and b), day 15 (c and d) and day 21 (e and f). In the control animals, the basal layer of stratified cuboidal epithelium exhibit positive ER $\alpha$-immunoreaction on days 10, 15 and 21 (a, $\mathbf{c}$ and $\mathbf{e}$ ); some cells locating superficial layers are also immunostained. Compressed nuclei of mucified cells also are positive on day 21 (e). In the DES-mice, cells of basal layer of the stratified squamous epithelium exhibit ER $\alpha$ immunostaining on day 10,15 and $21(\mathbf{b}, \mathbf{d}$ and $\mathbf{f})$. Bar $=50 \mu \mathrm{m}$.

the lumen $(2 / 6)$.

In the control animals, ER $\alpha$ immunostaining was seen in the basal layer cells of stratified cuboidal epithelium and gradually increased until day 15 (Figs. 4a, 5a); some cells of the upper layers of the epithelium also showed positive reaction on day 15 (Fig. 5c). The basal layer cells of stratified squamous epithelium and mucified cells showed a moderate immunoreaction on day 21 (Fig. 5e). In the DES-mice, columnar cells and basal layer cells of stratified epithelium showed moderate and weak reactions, respectively, on day 4 (Fig. 4b). From day 10 to day 21, the basal layer cells of stratified squamous epithelium showed positive immunostaining (Fig. 5b, d, f). Moderate ER $\alpha$-immunostaining was seen in the mucified cells. ER $\alpha$-immunostaining in the stromal cells was slightly weaker compared with that in controls until day 15.

\section{Localization of ER $\beta$}

Neonatal DES treatment caused no significant changes in the distribution pattern and expression of ER $\beta$ in female reproductive tissues. Positive ER $\beta$ immunostaining was observed only in the ovaries in both control and DES-mice 

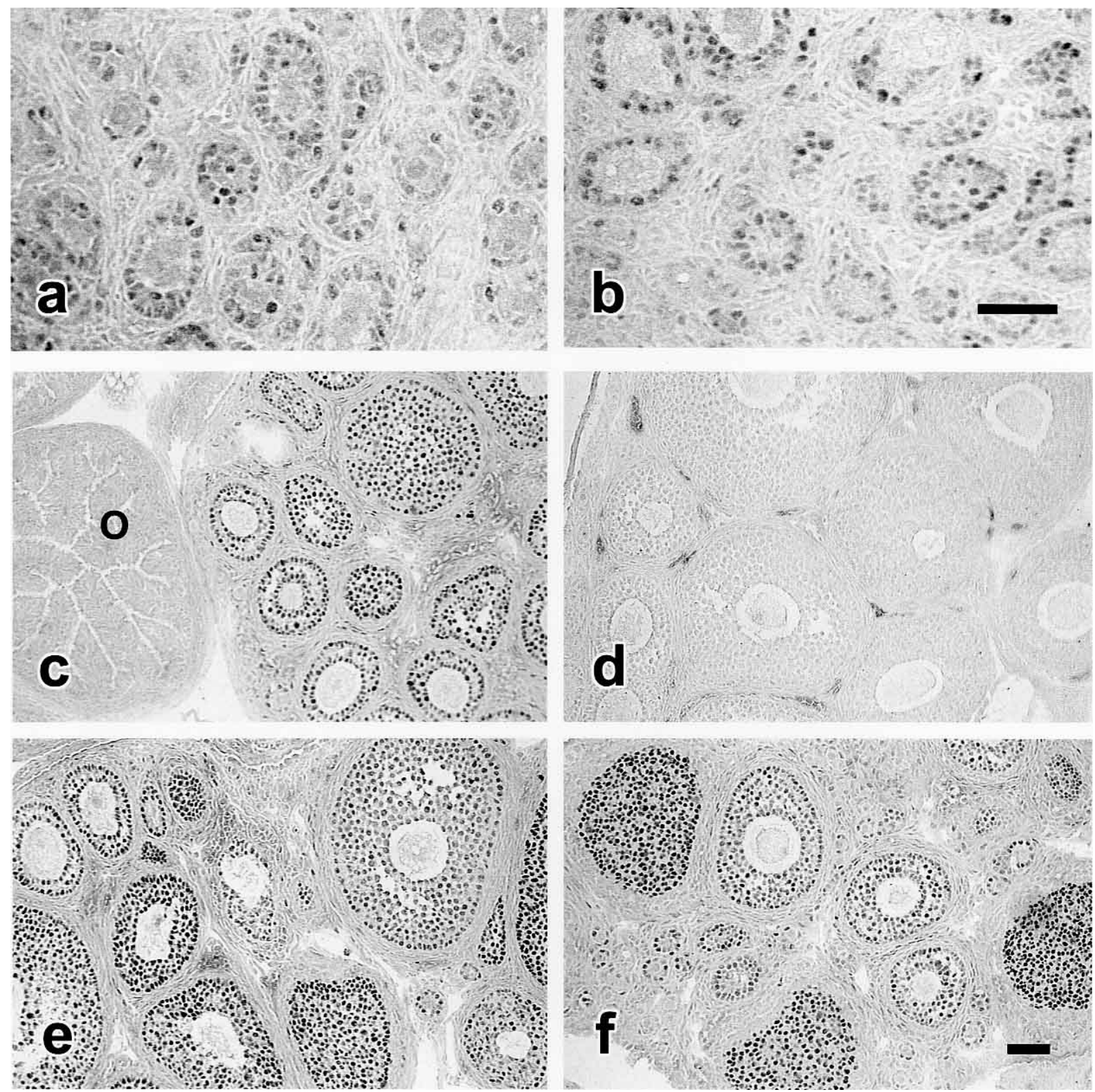

Fig. 6. Localization of ER $\beta$ protein in mouse ovaries. Sections are immunostained using the ER $\beta$ antibody (a, $\mathbf{b}, \mathbf{c}, \mathbf{e}$ and $\mathbf{f})$ and the pre-absorbed antibody with the antigenic peptide (d). Immunoreaction is shown in the ovaries of vehicle-treated control animals (a, $\mathbf{c}$ and $\mathbf{e})$ and of DES-mice $(\mathbf{b}, \mathbf{d}$ and $\mathbf{f})$ on days 4 (a and $\mathbf{b}), 15$ (c) and 21 (d, e and $\mathbf{f})$. Neonatal DES treatment causes no significant changes in the distribution pattern and expression of ER $\beta$. ER $\beta$-immunostaining is present in the nuclei of follicular cells in primordial and primary unilaminar follicles on day 4 (a and b) and in the granulosa cells on day 15 and 21 (c, $\mathbf{e}$ and $\mathbf{f})$ but not in the oviduct (c). No specific immunostaining is seen in the control section (d). $\mathrm{O}$, oviduct. Bars $=50 \mu \mathrm{m}(\mathbf{a}, \mathbf{b}), 50 \mu \mathrm{m}(\mathbf{c}-\mathbf{f})$.

during maturation.

Faint ER $\beta$-immunoreaction was present in the nuclei of follicular cells in primordial follicles and a weak reaction was seen in the follicular cells of primary unilaminar follicles on day 4 (Fig. 6a, b). Intensity of ER $\beta$-immunoreaction in the granulosa cells increased with the maturation of follicles (Fig. 6c, e, f). A few theca cells and stroma cells exhibited a positive ER $\beta$-immunoreaction.

Antibody pre-absorbed with immunizing peptide displayed no specific staining in either vehicle-treated control or DES-mice at any stages (Fig. 6d).

\section{Discussion}

The ontogeny of ER $\alpha$ in the female genital tract of vehicle-treated control mice was basically the same as the previous results examined with $\mathrm{H}-222$ monoclonal antibody in untreated normal mice $[37,39]$. The present study demonstrated that DES-treatment up-regulates the expression of $\mathrm{ER} \alpha$ in the epithelial cells in the oviducts, uteri, cervices and 
vaginae, and down-regulates the expression in the stromal cells at least until 10 days of age. These results were in almost complete agreement with the data shown by Taguchi et al. [31], Greco et al. [11] and Yoshida et al. [42]. Sato et al. [29] reported that ER $\alpha$-immunoreactivity in the vaginal epithelium gradually decreases with maturation in control mice, and that the neonatal DES treatment activates ER $\alpha$ expression in the uterine epithelium but somewhat suppresses it in the vaginal epithelium. The slight discrepancy in the ER $\alpha$ distribution in the vaginal epithelium may be due to the difference in the strains of mice examined. Effects of DES treatment continued in most tissues until days 10 to 15 . The prolonged effects of DES-exposure may be due to action of oxidative metabolite of DES, since Chae et al. [4] reported that the metabolite, DES-4',4"-quinone, can irreversibly bind ERs and activate estrogen responsive genes.

In the present study, ER $\beta$ was localized in the granulosa cells and some stromal cells in the ovary but not in other tissues during maturation in both control and DES-mice (Fig. 6). Weihua et al. [35] reported that ER $\beta$-immunoreaction was detectable in both the stroma and epithelium of the mouse uterus. However, Jefferson et al. [14] showed that no detectable levels of ER $\beta$-immunoreaction are present in the oviduct and uterus of mice during maturation. Couse et al. [6] reported that ER $\alpha$ is the predominant transcript in the oviduct, uterus, cervix and vagina but the ER $\beta$ transcript was detectable at a level of $5 \%$ or below that in the ovary in mature mice.

It is reported that $17 \beta$-estradiol and DES enhance the ERE mediated transactivation by $\mathrm{ER} \alpha$ and $\mathrm{ER} \beta$, whereas these estrogens enhance AP-1 mediated transactivation by $\mathrm{ER} \alpha$ and inhibit it by $\operatorname{ER} \beta[21,27]$. These results indicate that ER $\alpha$ is the essential ER isoform not only for the estrogen-dependent responses in the normal female genital tract but also for the induction of abnormal characteristics in the tissues of DES-mice. The present study demonstrated that neonatal DES exposure does not influence the distribution pattern of ER $\beta$ protein during the period of DES-treatment and subsequent postnatal development, and that the ER $\beta$ expression is a very low level in the genital tract. Cooke et al. [5] revealed that estrogen treatment did not induce the characteristic estrogenic responses in the uterus and vagina in the ER $\beta$ knockout mice. ER $\beta$ knockout mice had indistinguishable gross and histological structures in the female genital tissues compared with those of wild-type animals and were fertile.

The reproductive tract of newborn mice is responsive to exogenous estrogens, although neonatal development of the genital tract is considered independent of ovarian hormones, at least until day 15 [25]. The following results strongly suggested that the change of expression pattern of ER $\alpha$ during the periods of DES-treatment and prepubertal development are the dominant factors for the permanent alternation of cell activities. First, neonatal DES treatment highly activated $\mathrm{ER} \alpha$ expression in the epithelial cells and suppressed it in the stromal cells in the genital tract. Second, only the prenatal and early neonatal period are critical periods for the per- manent changes of genital tract elicited by exogenous estrogen administration. Third, Cunha and co-workers have demonstrated that the presence of ER $\alpha$ in both stromal and epithelial cells is necessary for the epithelial differentiation in the uterus and vagina in neonatal and mature mice based on the results of tissue recombination experiments between the mesenchyme (or stroma) and epithelium obtained from the uterus and vagina of wild-type and ER $\alpha$-knockout mice $[3,5,18]$.

Several studies have verified that neonatal DES exposure induces a persistent ovary-independent activation of estrogen-regulated genes, lactoferrin (LF), EGF and c-fos genes, in the mouse uterus and vagina $[15,23,40]$. Therefore, these results strongly suggest that the constitutive and mutual stimulation of the membrane-mediated signaling system, ER system and AP-1 system should cause the higher mitotic rates at steady-state in the epithelia of mature DESmice than in those of the controls, and plays important roles in the genesis of abnormalities in the reproductive tissues. One of the mechanisms of alteration of estrogen-regulated gene expression may be due to the demethylation or methylation of DNA in DES-mice. Li et al. [19] revealed that neonatal DES-treatment imprinted an abnormal, site-specific demethylation of immediately upstream of the ERE of LF promoter.

In summary, neonatal DES treatement stimulated ER $\alpha$ expression but had no effect on ER $\beta$ expression in the epithelial cells of female genital tract during postnatal development. The present study demonstrated that ER $\alpha$ is the essential ER isoform not only for the estrogen-dependent responses in the normal female genital tract but also for the induction of abnormal characteristics in the tissues of DESmice. In addition, it is suggested that ER $\alpha$ expression and stimulation of ER $\alpha$ systems in the critical differentiation periods should be responsible for the development of severe lesions of the reproductive tract.

\section{Acknowledgments}

The author would like to thank Kazuya Funato for help with the figures. This work was supported in part by Grantin-Aid 11670030 for Scientific Research from the Ministry of Education, Science and Culture, Japan, and by a grant from the Keio Gijuku Academic Development Fund.

\section{References}

1. Bern, H. A., Jones, L. A., Mori, T. and Young, P. N. (1975) Exposure of neonatal mice to steroids: Longterm effects on the mammary gland and other reproductive structures. J. Steroid Biochem. 6; 673-676.

2. Bigsby, R. M. and Cunha, G. R. (1986) Estrogen stimulation of deoxyribonucleic acid synthesis in uterine epithelial cells which lack estrogen receptors. Endocrinology 119; 390-396.

3. Buchanan, D. L., Kurita, T., Taylor, J. A., Lubahn, D. B., Cunha, G. R. and Cooke, P. S. (1998) Role of stromal and epithelial estrogen receptors in vaginal epithelial proliferation, stratification, and cornification. Endocrinology 139; 4345-4352. 
4. Chae, K., Lindzey, J., McLachlan, J. A. and Korach, K. S. (1998) Estrogen-dependent gene regulation by an oxidative metabolite of diethylstilbestrol, diethylstilbestrol-4',4"-quinone. Steroids 63; 149-157.

5. Cooke, P. S., Buchanan, D. L., Young, P., Setiawan, T., Brody, J., Korach, K. S., Taylor, J., Lubahn, D. B. and Cunha, G. R. (1997) Stromal estrogen receptors mediate mitogenic effects of estradiol on uterine epithelium. Proc. Natl. Acad. Sci. U S A 94; 65356540 .

6. Couse, J. F., Lindzey, J., Grandien, K., Gustafsson, J. A. and Korach, K. S. (1997) Tissue distribution and quantitative analysis of estrogen receptor- $\alpha(\mathrm{ER} \alpha)$ and estrogen receptor- $\beta(\mathrm{ER} \beta)$ messenger ribonucleic acid in the wild-type and ER $\alpha$-knockout mouse. Endocrinology 138; 4613-4621.

7. DiAugastine, R. P., Petruse, P., Bell, G. I., Brown, C. F., Korach, K. S., McLachlan, J. A. and Teng, C. T. (1988) Influence of estrogens on mouse uterine epidermal growth factor precursor protein and messenger ribonucleic acid. Endocrinology 122; 2355-2363.

8. Forsberg, J.-G. (1977) Developmental mechanism of estrogeninduced irreversible changes in the mouse cervicovaginal epithelium. Natl. Cancer Inst. Monogr. 51; 41-56.

9. Gaub, M.-P., Bellard, M., Scheuer, I., Chambon, P. and SassoneGorsi, P. (1990) Activation of ovalbumin gene by estrogen receptor involves the Fos-Jun complex. Cell 63; 1267-1276.

10. Greco, T. L., Furlow, J. D., Duello, T. M. and Goroski, J. (1991) Immunodetection of estrogen receptors in fetal and neonatal female mouse reproductive tracts. Endocrinology 129; 1326-1332.

11. Greco, T. L., Duell, T. M. and Gorski, J. (1993) Estrogen receptors, estradiol, and diethylstilbestrol in early development: the mouse as a model for the study of estrogen receptors and estrogen sensitivity in embryonic development of male and female reproductive tracts. Endocr. Rev. 14; 59-71.

12. Hasegawa, H., Mizuhira, V. and Notoya, M. (2000) Microwavestimulated fixation and histochemical application to biological specimens. Acta Histochem. Cytochem. 33; 319-340.

13. Iguchi, T. (1992) Cellular effects of early exposure to sex hormones and antihormones. Int. Rev. Cytol. 139; 1-57.

14. Jefferson, W. N., Couse, J. F., Banks, E. P., Korach, K. S. and Newbold, R. R. (2000) Expression of estrogen receptor $\beta$ is developmentally regulated in reproductive tissues of male and female mice. Biol. Reprod. 62; 310-317.

15. Kamiya, K., Sato, T., Nishimura, N., Goto, Y., Kano, K. and Iguchi, T. (1996) Expression of estrogen receptor and protooncogene messenger ribonucleic acids in reproductive tracts of neonatally diethylstilbestrol-exposed female mice with or without postpuberal estrogen administration. Exp. Clin. Endocrinol. Diabetes 104; 112-122.

16. Korach, K. S., Horigome, T., Tomooka, Y., Yamashita, S., Newbold, R. R. and McLachlan, J. A. (1988) Immunodetection of estrogen receptor in epithelial and stromal tissues of neonatal mouse uterus. Proc. Natl. Acad. Sci. U S A 85; 3334-3337.

17. Kuiper, G. G., Carlsson, B., Grandien, K., Enmark, E., Haggblad, J., Nilsson, S. and Gustafsson, J. A. (1997) Comparison of the ligand binding specificity and transcript tissue distribution of estrogen receptors $\alpha$ and $\beta$. Endocrinology 138; 863-870.

18. Kurita, T., Lee, K. J, Cooke, P. S., Taylor, J. A., Lubahn, D. B. and Cunha, G. R. (2000) Paracrine regulation of epithelial progesterone receptor by estradiol in the mouse female reproductive tract. Biol. Reprod. 62; 821-830.

19. Li, S., Washburn, K. A., Moore, R., Uno, T., Teng, C., Newbold R. R., McLachlan, J. A. and Negishi, M. (1997) Developmental exposure to diethylstilbestrol elicits demethylation of estrogenresponsive lactoferrin gene in mouse uterus. Cancer Res. 57; 4356-4359.

20. MaLachlan, J. A. (1981) Rodent models for perinatal exposure to diethylstilbestrol and their relation to human disease in the male.
In "Developmental Effects of Diethylatilbestrol (DES) in Pregnancy", ed by A. L. Herbst and H. A. Bern, Thieme-Stratton Inc., New York, pp. 148-157.

21. Murayama, S., Fujimoto, N., Asano, K. and Ito. A. (2001) Supression by estrogen receptor $\beta$ of AP-1 mediated transactivation through estrogen receptor $\alpha$. J. Steroid Biochem. Mol. Biol. 78; 177-184.

22. Nelson, K. G., Takahashi, T., Bosser, N. L., Walmer, D. K. and McLachlan, J. A. (1991) Epidermal growth factor replaces estrogen in the stimulation of female genital tract growth and differentiation. Proc. Natl. Acad. Sci. US A 88; 21-25.

23. Nelson, K. G., Sakai, Y., Eitzman, B., Steed, T. and McLachlan, J. A. (1994) Exposure to diethylstilbestrol during a critical developmental period of the mouse reproductive tract leads to persistent induction of two estrogen-regulated genes. Cell Growth Differ. 5; 595-606.

24. Newbold, R. R., Bullock, B. C. and McLachlan, J. A. (1985) Progressive proliferative changes in the oviduct of mice following developmental exposure to diethylstilbestrol. Teratog. Carcinog. Mutagen. 5; 473-480.

25. Ogasawara, Y., Okamoto, S., Kitamura, Y. and Matsumoto, K. (1983) Proliferative pattern of uterine cells from birth to adulthood in intact, neonatally castrated, and/or adrenalectomized mice, assayed by incorporation of $\left[{ }^{125} \mathrm{I}\right]$ iododeoxyuridine. Endocrinology 113 ; 582-587.

26. O’Malley, B. W., Scharder, W. T., Mani, S., Smith, C., Weigel, N. L., Conneely, O. M. and Clark, J. K. (1995) An alternative ligand-independant pathway for activation of steroid receptors. Rec. Prog. Hormone Res. 50; 333-347.

27. Paech, K., Webb, P., Kuiper, G. G., Nilsson, S., Gustafsson, J. A., Kushner, P. J. and Scanlan, T. S. (1997) Differential ligand activation of estrogen receptors ER $\alpha$ and $\mathrm{ER} \beta$ at AP1 sites. Science 277; 1508-1510.

28. Pfahl, M. (1993) Nuclear receptor/AP-1 interaction. Endocr. Rev. $14 ; 651-658$.

29. Sato, T., Okamura, H., Ohta, Y., Hayashi, S., Takamatsu, Y., Takasugi, N. and Iguchi, T. (1992) Estrogen receptor expression in the genital tract of female mice treated neonatally with diethylstilbestrol. In Vivo 6; 151-156.

30. Sato, T., Ohta, Y., Okamura, H., Hayashi, S. and Iguchi, T. (1996) Estrogen receptor (ER) and its messenger ribonucleic acid expression in the genital tract of female mice exposed neonatally to tamoxifen and diethylstilbestrol. Anat. Rec. 244; 374-385.

31. Taguchi, O., Bigsby, R. M. and Cunha, G. R. (1988) Estrogen responsiveness and the estrogen receptor during development of the murine female reproductive tract. Develop. Growth Differ. 30; 301-311.

32. Takasugi, N. (1976) Cytological basis for permanent vaginal changes in mice treated neonatally with steroid hormones. Int. Rev. Cytol. 44; 193-224.

33. Tremblay, A., Tremblay, G. B., Labrie, F. and Giguere, V. (1999) Ligand-independent recruitment of SRC-1 to estrogen receptor $\beta$ through phosphorylation of activation function AF-1. Mol. Cell. 3; 513-519.

34. Tyulmenkov, V. V. and Klinge, C. M. (2000) Selectivity of antibodies to estrogen receptors $\alpha$ and $\beta$ (ER $\alpha$ and $E R \beta)$ for detecting DNA-bound ER $\alpha$ and ER $\beta$ in vitro. Steroids $65 ; 505-512$.

35. Weihua, Z., Saji, S., Makinen, S., Cheng, G., Jensen, E. V., Warner, M. and Gustafsson, J. A. (2000) Estrogen receptor (ER) $\beta$, a modulator of ER $\alpha$ in the uterus. Proc. Natl. Acad. Sci. US A 97; 5936-5941.

36. Weihua, Z., Makela, S., Andersson, L. C., Salmi, S., Saji, S., Webster, J. I., Jensen, E. V., Nilsson, S., Warner, M. and Gustafsson, J. A. (2001) A role for estrogen receptor $\beta$ in the regulation of growth of the ventral prostate. Proc. Natl. Acad. Sci. US A 98; 6330-6335. 
37. Yamashita, S., Newbold, R. R., McLachlan, J. A. and Korach, K. S. (1989) Developmental pattern of estrogen receptor expression in female mouse genital tracts. Endocrinology 125; 2888-2896.

38. Yamashita, S., Takayanagi, A. and Shimizu, N. (1999) c-Fos and c-Jun expression in the uterus of neonatally estrogen exposed mice. Acta Histochem. Cytochem. 32; 536.

39. Yamashita, S. (2001) Histochemistry and cytochemistry of nuclear receptors. Prog. Histochem. Cytochem. 36; 91-176.

40. Yamashita, S., Takayanagi, A. and Shimizu, N. (2001) Effects of neonatal diethylstilbestrol exposure on c-fos and c-jun protooncogene expression in the mouse uterus. Histol. Histopathol. 16;
$131-140$

41. Yasuda, K., Yamashita, S., Aiso, S., Shiozawa, M. and Komatsu, T. (1986) Immunohistochemical study of $\gamma$-glutamyl transpeptidase with monoclonal antibodies. I. Preparation and characteristics of monoclonal antibodies to $\gamma$-glutamyl transpeptidase. Acta Histochem. Cytochem. 19; 589-600.

42. Yoshida, A., Newbold, R. and Dixon, D. (2000) Abnormal cell differentiation and p21 expression of endometrial epithelial cells following developmental exposure to diethylstilbestrol (DES). Toxicol. Pathol. 28; 237-245. 